\title{
An Application of Arabic Language Teaching Based on Error Analysis Theory
}

\author{
Abdul Hafidz Zaid ${ }^{1}$, Imam Bahroni ${ }^{2}$ and Ahmad Hifdzil Haq ${ }^{3}$ \\ \{abuafadh@unida.gontor.ac.id, ${ }^{1}$ mas.bahroni@gmail.com, ${ }^{2}$ hifdzil.haq@ mhs.unida.gontor.ac.id ${ }^{3}$ \} \\ 1,2,3 Department of Arabic Language Teaching Postgraduate Program, University of Darussalam \\ Gontor, J1. Raya Siman No.Km. 6, Dusun I, Siman, Kabupaten Ponorogo, Jawa Timur 63471; 1,2,3
}

\begin{abstract}
Islamic Boarding School is an Indonesian Islamic education institution that has great attention to learning Arabic. To improve student language, this institution teach composition systematically in the Insya' lessons. However, the Institute continues to face considerable difficulties in learning the Arabic language. Those difficulties appear in the high frequency of errors in the structure of Arabic Sentence. The purpose of this study was to design the Student Worksheet materials based on linguistic error analysis of students in their composition, as an alternative in solving the problems to improve Arabic language skills. The results of the study is that using the linguistic errors analysis to design the Student Worksheet materials is very useful and able to reduce the linguistic errors in the student's composition. It was shown by the high posttest result when compared with pretest result.
\end{abstract}

Keywords: Composition; The Design of Student Worksheet Materials; Error Analysis.

\section{Introduction}

Composition is the most important function of language [1] as a means of human communication to express intentions [2], [3]. Because language is a link between humans and other communities [4], [5]. Therefore, language learning needs to focus on the ability of composition, both oral (syafawi) and written (tahriri). Based on this, it is the ultimate goal in learning, while other branches of linguistics are considered as attainment of the achievement of these goals [6].

Al-Iman Putra Islamic Boarding School since its establishment until now still shows great attention and places great emphasis on the deepening of Arabic as the standard language of learning and the everyday language of students. The Islamic boarding school teaches Insya lessons to support the abilities of Composition. The aim of the lesson is the ability of students in Composition according to the rules of the Arabic language that is right and right, with basic competence students are able to choose words and arrange them in sentences, students can compose essays with correct language structure and good language style, students can express their opinions and thoughts with the correct expressions and students have the right sense of Arabic [7].

To achieve the goals and basic competencies above, Boarding school teaches it in class II to class VI KMI. Class II KMI is the initial period for Composition learning, so the teaching needs to be packaged as attractive as possible. But unfortunately, students still face difficulties. The difficulty is evident from the low scores of the Initiative Class II KMI lessons in the last 3 
years. The weak value is derived from the number of students' mistakes that are quite serious in making Arabic sentence structure.

This happens because of the negative transfer or interference of the first language in the second language (Arabic) and the occurrence of intralingual, namely errors due to the development of the language being studied comes from inadequate mastery of the second language (Arabic). The percentage of linguistic interference and intralingual errors is $28 \%$ compared to $71 \%$, the second error is more dominant than the first. With that, systematic research is needed to find a formula that aims to resolve these difficulties.

The theory of language error analysis is a modern linguistic study, in this case, it can be applied, given that it has practical benefits. Practically can support the methodological aspects of language teaching, and the results of error analysis can be an evaluation to improve and enhance second language learning. One concrete form is the improvement of the quality of teaching materials that are designed or developed through structuring, selecting and sorting the presentation of material based on the common forms of mistakes made by the learner [8], [9].

Remembering language is a skill that comes from habit, with the ability to composition as the final destination. Then the most appropriate effort is the presentation of Student Worksheets as teaching materials that are concise and rich in tasks for practice [10], with practical skills [10] that do not overload students on memorizing the rules [11], the method of pattern drill to build students 'spontaneous analogies [12] in composition (syafawi and tahriri), coupled with the use of interesting images, on the basis of using data from forms of learner errors that have been analyzed, are able to contribute to the suitability of student learning needs [13]. Thus, the Student Worksheet is the best solution for developing the ability of Composition students, as well as attracting students who then activate students more, function as material reinforcement and help make it easier for them to understand the material.

\section{Composition learning and Student Worksheets}

Humans are social creatures who cannot stand alone without the help of others. This situation makes language a very important need for them, because it is a reflection of the intellect and feelings with which they can communicate with each other [14], the reflective form is manifested in the expression (composition). So, it is not excessive if language is called a tool used by humans in expressing and expressing intentions and goals.

Terma Composition (Ta'bir) is etymologically a word formed from 'abbara - yu'abbiruta'biran meaning is to explain and interpret [15] or ibanah and ifshah means explanation [16]. As for the terminology, varied linguists interpret it in some language teaching literature. According to Ahmad, Ta'bir is a reference or composition written by someone who comes from his ideas and feelings to meet all his needs in life [15]. Furthermore, Dulaimy in this case adds to the previous explanation and puts composition in a learning that needs to be systematically trained in accordance with a mature plan, so that it can achieve what is desired at the level where a person can express his ideas, ideas, and feelings that originate from what is seen and from the experience of living in the right language in accordance with certain pathways [17]. No different from the two linguists above Madkur then detailed in detail, he stated that composition is subtle language creativity both verbally and in writing, while the operational definition is the ability to master a language as a medium for expressing ideas and ideas and communicating them [18].

From some of the definitions of the composition above, a conclusion can be drawn that composition is systematic creativity that runs according to a mature plan so that one can express his ideas, ideas and feelings by using appropriate language both oral (syafawi) and written (tahriri). 
In practice, the composition is done by two methods, namely oral (syafawi) and written (tahriri). Write composition is no less important than oral composition, because he can realize what cannot be accomplished by oral composition. Somewhat different from spoken language, written language knows far more sets of rules or rules. Also, writing is present to ensure that contacts can continue even if there is a distance, both space and time. As for a direct conversation, if " $\mathrm{A}$ " feels unsure of what his intentions are understood by " $\mathrm{B}$ " he can immediately and there, improve his speech. If necessary, he can reinforce it with elements from outside the language, such as sound pressure, tempo, expression or body language [6].

Coherent and interesting learning is needed in composition learning. Write composition Interesting learning means having an element of "tickling" for students to follow and match the atmosphere of student psychology. That way students have the motivation to continue to follow learning [19].

For that composition learning needs to use appropriate teaching methods and materials, one of which is by using Image Media. Pictures and photos are helpful tools to assist students in constructing sentences on composition abilities [20].

As for the steps in composition teaching by using pictures, students are asked to describe the picture orally, giving several questions related to the theme of the picture, students are asked to describe what is seen in the picture, which is in the form of daily activities and so forth [21]. By compiling composition teaching materials with the Student Worksheet-shaped drawing method, can make it easier for students to arrange sentences and can make students excited in improving their language.

Student Worksheet one of the teaching materials according to its form is classified as printed teaching materials. It is one of the learning resources that can be developed by the teacher as a facilitator in learning activities. Also, it can be designed and developed according to the conditions and situations of learning activities that will be encountered [22]. Student Worksheet is sheets of assignments that must be done by students. Activity sheets are usually in the form of instructions or steps to complete a task. And, the task must be clear the basic competencies to be achieved [10].

According to another view Student Worksheet is a student worksheet that is a material student worksheet that has been packaged in such a way that students are expected to be able to study these teaching materials independently. In Student Worksheet, students will get material, summaries, and assignments related to the material. Also, students can find a structured direction for understanding the material provided. and, at the same time, students can be given material and assignments related to the material [10].

The uses of the Student Worksheet include; first, as a concise teaching material, rich in the task of practicing as well as the material makes it easier for students to understand the material. Second, as a reinforcement of the material provided. Third, help students find a concept and integrate it [9] in textbooks so that it can be a companion book [23].

Judging from the function above, several benefits are found in the worksheet, which is as attractive teaching material for students, thus encouraging them to study hard and smart [24], develop students' thinking abilities and encourage students to do practical work to concretize concepts [25].

Continuing the matter Judging from its structure, teaching materials Student Worksheet is simpler than Modules, but more complex than books. Student Worksheet learning materials consist of six main elements, including Title, study instructions, basic competencies/ subject matter, supporting information, assignments or work steps and assessment [10]. So in its preparation through several steps: [10] Curriculum analysis, this step is intended to determine which materials require worksheets. In general, in determining the material, steps taken by 
looking at the main material, learning experience, and the material to be taught. Next, we must look at the competencies students must have.

Compile a map of needs, It is very necessary to know the number of worksheets that must be written and see the sequence or sequence of the worksheets. This sequence is needed to determine the priority of writing. This step usually begins with an analysis of the curriculum and learning resources. Determine the worksheet titles, the worksheet titles are determined based on basic competencies, subject matter, or learning experiences contained in the curriculum. One basic competency can be used as a worksheet title if the competency is not too large. Composition Student Worksheet, by Formulate basic competencies, Determine assessment tools, Arrange material, Pay attention to the structure of the worksheet.

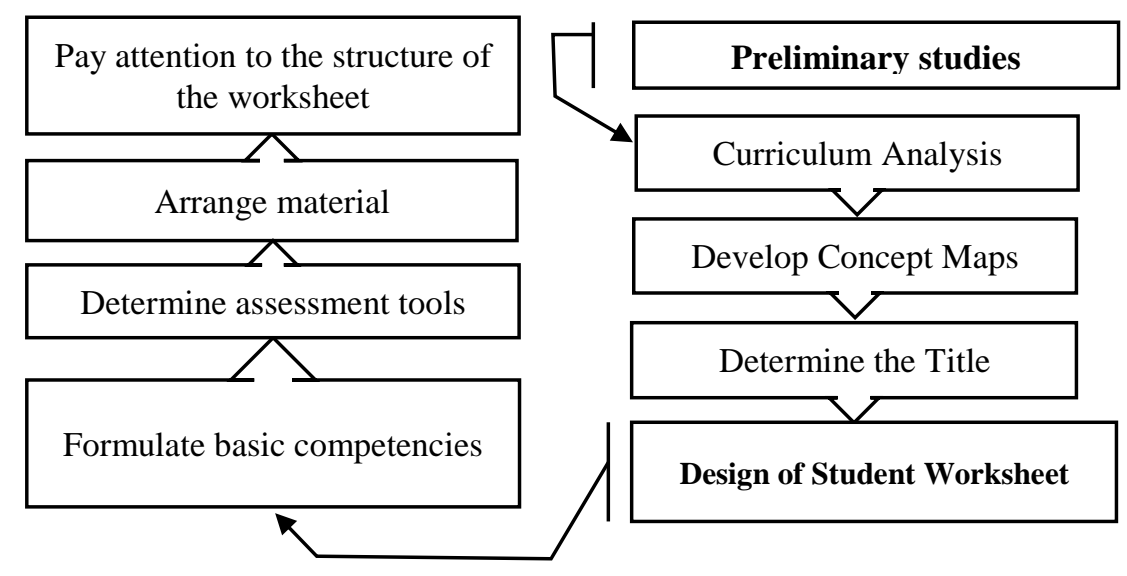

Fig. 1. Steps For Designing Student Worksheet.

\section{Error Analysis}

Language errors are seen as part of the language learning process. This means that language errors are an integral part of language acquisition and teaching. The relationship between language teaching and language mistakes is very close. Even Tarigan said that their relationship was like water with fish. Just as fish can only live and are in water, so language errors often occur in language teaching [9].

Based on the source, the cause of language errors in language contact that occurs in bilingual, which causes mutual influence between the elements of the language (B1 B2). In language contact (B1 and B2), there is a transfer of language elements. If the language elements transferred to make it easy for students in the process of learning and teaching language, then it is called positive transfer. If the elements of the language transferred make students difficult and wrong in a language then it is called negative transfer or interference. So interference is one of the causes of students getting into trouble and mistakes or mistakes in the process of acquiring and learning language (B2) [26].

Besides that, language mistakes are not only made by students who learn B2 (Language students learn) but also are made by students who learn BL (Mother Language). In this connection, the experience of the teachers in the field stated that the language mistakes made by students were often unexpected. This means that there are errors that are in line with the forecast but many are also outside the teacher's forecast. There are errors caused by interference, but some are caused by overgeneralization, not understanding the language of rules (ignorance 
of rule restriction), paying less attention to the language method (incomplete application of rules), and the existence of incorrect hypotheses about language. Linguistics experts and language teachers agree that language mistakes interfere with the achievement of language teaching goals. Therefore, language errors that are often made by students must be reduced or eliminated [8].

Continuing with the case it is necessary to know that the error in the language is not the same as the mistake in language, even though both of them are the use of distorted forms of speech. Language errors occur systematically because the language system rules have not yet been mastered, in other words, language errors occur due to speakers violating rules or grammar rules (breaches of code). Unlike the case with language errors, it does not occur systematically, not because the system of language rules has not yet been mastered, but because of the failure to realize the language system that has been mastered [8], [27].

Related to that, analysis of language errors can be helpful and even very useful as a means of smooth teaching programs being implemented. In other words, by analyzing the mistakes of teachers or textbook writers, they can overcome the difficulties students face. A teacher in teaching language often finds mistakes made by his students. These mistakes can involve language skills such as listening, speaking, reading and writing. However, it can also relate to linguistics, such as speech, word order, and sentence structure.

Error Analysis (tahlil al-akhtho`al-lughowiyah) is part and continuation of contrastive analysis (tahlil taqobuliy) which began to develop since the second half of the 60 [8]. These two forms of analysis have in common, namely language as the object of study. It's just that the analysis of language errors is intended for the learner's language, not in his native language, but in the foreign language he is learning [28].

In his understanding of Error Analysis is a work procedure. As a work procedure or method, Error Analysis has certain work steps [9]. This is done to identify, classify, interpret systematically the mistakes made by students who are studying a foreign language or a second language by using scientific theories and linguistic procedures [29].

From another aspect, error analysis can foster teacher insights in teaching and overcoming language difficulties faced by language learners. Mistakes can help organize teaching material and carry out teaching. The time and utilization of teaching can be allocated and planning can be carried out properly. During the teaching program, the analysis of language errors appears on a limited scale. Nevertheless, it can reveal whether the language teaching program that is being worked on by the teacher is successful or failed. If it fails, it needs to think about how the treatment (remedial) [30].

Analyzing language mistakes made by the language learner can provide certain benefits because understanding the mistakes is useful feedback for evaluating and planning the preparation of materials and language teaching strategies in class. Thus, it can be said that error analysis aims to: determine the order in which items are taught in class and textbooks, for example, the order from easy to difficult, from simple to complex, and continuously determine the level of emphasis, explanation, and training various items taught, planning training and remedial teaching, selecting items for testing student skills [9].

As for the general steps of error analysis carried out in the following order [31], [32]: First, Data collection. This stage includes: determining the area of the sample, the form of samples in the form of oral and written [31], carried out through daily tests or tests deliberately planned for analysis purposes [9], [30]. The data to be analyzed in the form of the work of learners who demand them to produce a language sequence, as well as linking it with elements of thought, to obtain a picture of the learner's ability to use language following the communicative function factually [33]. 
Second, Identifying errors. Done by recording every error that appears in the data. This requires a high level of mastery on the part of the researcher regarding the target language, as well as sensitivity and accuracy to recognize forms of error [31]. If not, it is very likely that many errors will be missed so that the analysis results are not optimal. The reference standard is the language of the eloquent people who are used in formal situations [33].

Third, Description of the error. Namely linguistic analysis of the errors that have been identified, by explaining the form of deviations in each error accompanied by speech reconstruction by showing the correct form. Reconstruction is based on authoritative interpretation, produced by first asking the learner directly about the intent he wants to convey in the first language. If it is difficult, the researcher can interpret it based on the linguistic context or the context of the situation.

Fourth, Explain errors. Unlike the error description, which is linguistic with the aim of analyzing the language of the forms of deviation in each error, the explanation of the error is psycholinguistic with the aim of recognizing the source and cause of the errors, for example: transfer of the first language to the target language, the process of mastery development target language, teaching-learning process, and others.

Fifth, Classifying Errors. This stage is done by grouping errors into several categories based on the similarity of their nature according to the limits that have been taken by the researcher. Each group of errors is then counted so that the level of seriousness can be calculated. From this step, conclusions can be drawn about areas of the target language that are the fault points of learners.

Sixth, Evaluate errors. In the final stage of error analysis, an evaluation of the results of the analysis is carried out to develop suggestions for improving language learning in the future. Thus, analysis of language errors is expected to provide pedagogical value to improving the quality of learners [33].

\section{Methodology}

To achieve maximum results, the Design Model for Arabic teaching materials for students uses the Research and Development (R\&D) research method [34]. Research and development are methods used to develop and validate products used in education and learning [35]. The selection of this method is following the purpose of the research to develop and test the effectiveness of the product that will be used in Composition's learning, which is preceded by an analysis of the language errors of students in class II KMI Al-Iman Boarding School for Male.

In collecting data, researchers used the method of Documentary, Observation, Test, and Questionnaire, so that this research instrument was the result of student composition, observation guidelines, test questions, and questionnaires. To analyze the data collected, researchers used a descriptive percentage formula and t-test formula. The results of the design were tested on experts in the fields of material, media, and learning. After that, a field test was conducted involving 63 students. In this study, researchers used qualitative and quantitative approaches, to obtain product effectiveness in the form of differences in the results before the product trial and after the trial. The target population is class II KMI Al-Iman Islamic Boarding School for males. 


\section{Results and Discussion}

\subsection{Error Analysis in Composition of Class II KMI}

Researchers found that students' mistakes stemmed from Mother's Linguistic Interference (Indonesian Language) and Intralingual and Developmental errors. Indonesian interference errors can be seen in the following sentence:

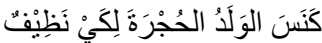

The use of the letter كي in the above sentence violates Arabic cyclic rules, which are usually not followed afterward by isim but more on fiil mudhari 'manshub, so precisely the sentence is

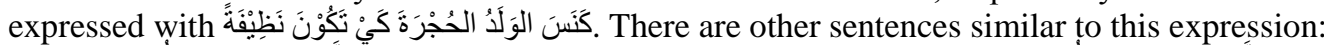

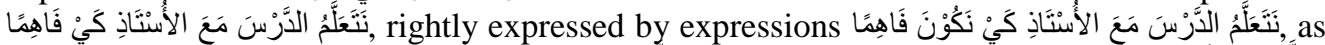

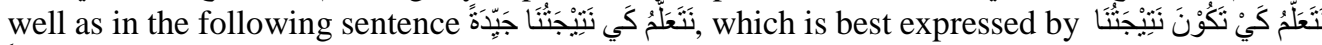
جَيِدَةً

In connection with this phenomenon, Indonesians express in their language the word "in order" as written in this expression:

- Di sekolah tugas kita adalah belajar agar naik kelas.

- Rumah di sapu agar bersih dari kotoran

- Polisi mengatur lalu lintas jalan agar tidak macet

- Ia minum obat agar lekas sembuh[36]

The word "agar" in Indonesian grammar is a conjunction that connects two sentences and indicates the desired purpose. Unlike the Arabic sentence, the word "agar" which means كي is a harf mashdary and nashab followed after fiil mudhari 'mansub [37].

In this case, students seem to try to use the analogy they built from the Indonesian language system to express Arabic sentences. First language interference in the second language occurs because the student's first language system is more dominant than the second language system [38].

The dominance of the first language in the second language again occurs in the expression

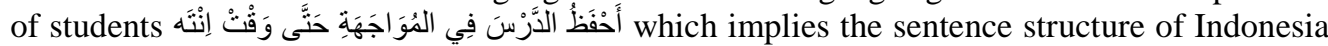

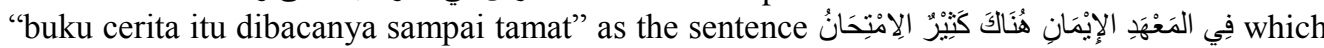
refers to the Indonesian expression "Selama ada masyarakat dan kehidupan disana ada hukum".

Composition's mistakes most students come from intralingual and developmental errors. As seen in the following error:

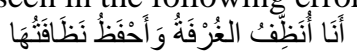

In the sentence structure above is an example that violates Arabic syntax rules, namely the

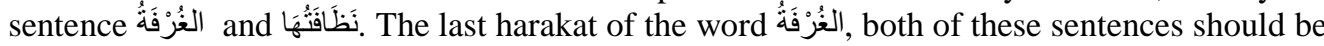
read as a text because their position is as maf'ul bihi. Likewise in the other sentence structures that have been collected by researchers, the following samples are obtained:

Table 1. The form of Composition students' mistakes.

\begin{tabular}{|c|c|}
\hline Composition students' mistakes & Correct sentence structure \\
\hline فِي الَبَيْتِ حُجْرَةُ لِي حُجْرَةُ بَابُّ & 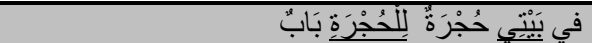 \\
\hline 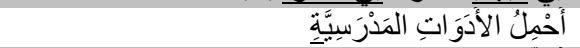 & 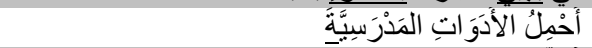 \\
\hline أنَعَلَمُ بِالجِدِّ وَالإِجْتِهَادُ & أَتَعَلَمُ بِالِجدِّ وَالإِجْتِهَادِ \\
\hline 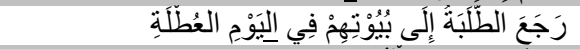 & 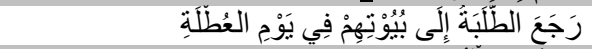 \\
\hline مَسنكِنِي سَوَى مُنَلُْ فِي بَيْتِي & 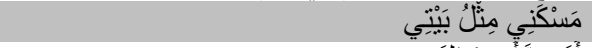 \\
\hline أَنَوَضَضَّعُعْ بعْدَ نَوْرِ & أَتَوَضَضَّأُ بَعْدَ الِنَْْرِ \\
\hline
\end{tabular}


As for when calculated and percentage can be seen in the graph below:

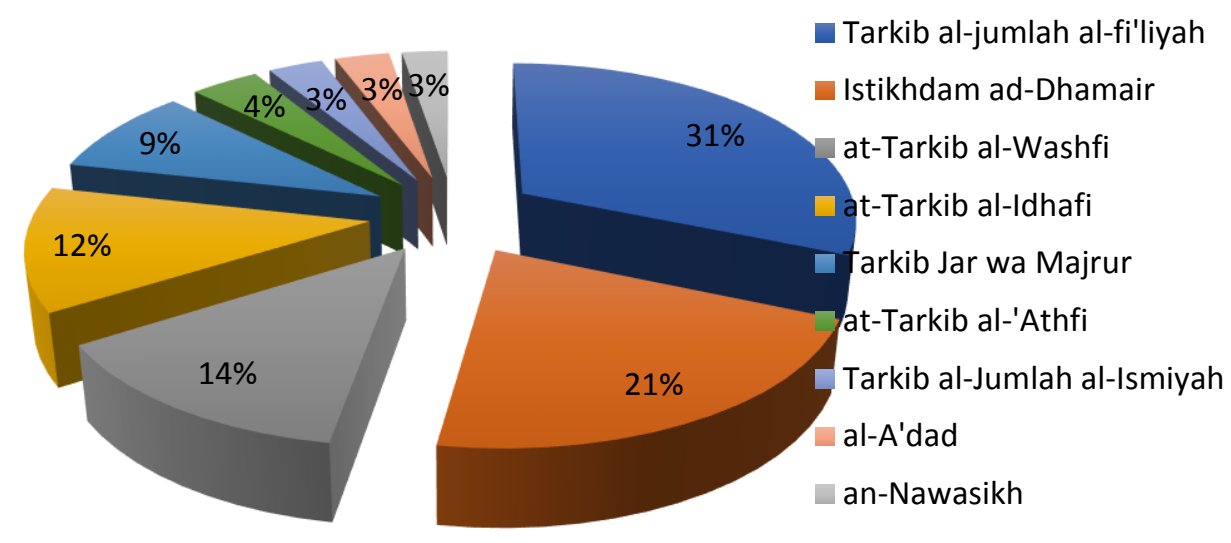

Fig. 2. Frequency of error.

\subsection{Desain Student Worksheet Materials}

After analyzing students' mistakes, the worksheets are arranged through the forms of mistakes of the second-grade students of KMI Al-Iman Boarding School for males. Student Worksheet is printed with paper size B5, space 1.5, font 18 KFGQPC Uthmanic Script HAFS for Arabic and Palatino Linotype for Indonesian. The worksheet design consists of front cover and back cover, introduction, table of contents, introduction, worksheet, training models, instructions for using the worksheet, syllabus, content, assessment, and bibliography. The contents section consists of the title of the material, the main paper, the elements of the paper, the explanation of the sentence structure in the paper, attention to errors, rules of pictorial or summary material, practice questions.

The titles of contained in the worksheet consist of 9 types, namely al-Jumlah al-Fi'liyah, Istikhdam ad-Dhomir, at-Tarkib al-Washfi, at-Tarkib al-Idhafi, at-Tarkib Jar wa Majrur, atTarkib al-'Afifi, al-Jumlah al-Ismiyah, Tarkib al-'Adad wa al-Ma'dud and an-Nawasihk. While the model and forms of training consist of Ikmal al-faraghat, takwin jumal bil kalimah mu'ayyanah, istikhraj at-thalabah min al-maqalah, al-istibdal, ishlah al-khata ', tarjamah aljumal, talkhish al-maqalah, wadh'u al-jumal ba'da mulahadhata an-namudzaj, akhtiyaru alanswer as-saheeh, tartibu al-sentences, ta' lifu al-maqalah, and ijabatu al-as'ilatu.

The content of the worksheet is enriched with pictures related to the material, wise words that aim to motivate students in learning Arabic and also the colors of the helpers in understanding Arabic sentence structure to encourage interest and reduce boredom due to new things in learning.

The contents of the worksheets were responded by material experts, media, languages, and students. Qualification of expert, practitioner and student response, namely (i) very high and high, it is necessary minor revisions are made and validation / retrying is not necessary; (ii) moderate, necessary major revisions are made and there is no need for validation / retrying; (iii) low and very low, large revisions / trials and re-validation need to be done, furthermore in the evaluation criteria for responses to Student Worksheet $81 \%$ - 100\% (highly applicable); 61\% $80 \%$ (can be applied); $41 \%$ - 60\% (enough can be applied); $21 \%-40 \%$ (less applicable); <21\% 
(not applicable). The results of expert and practitioner responses can be seen in the following graph:

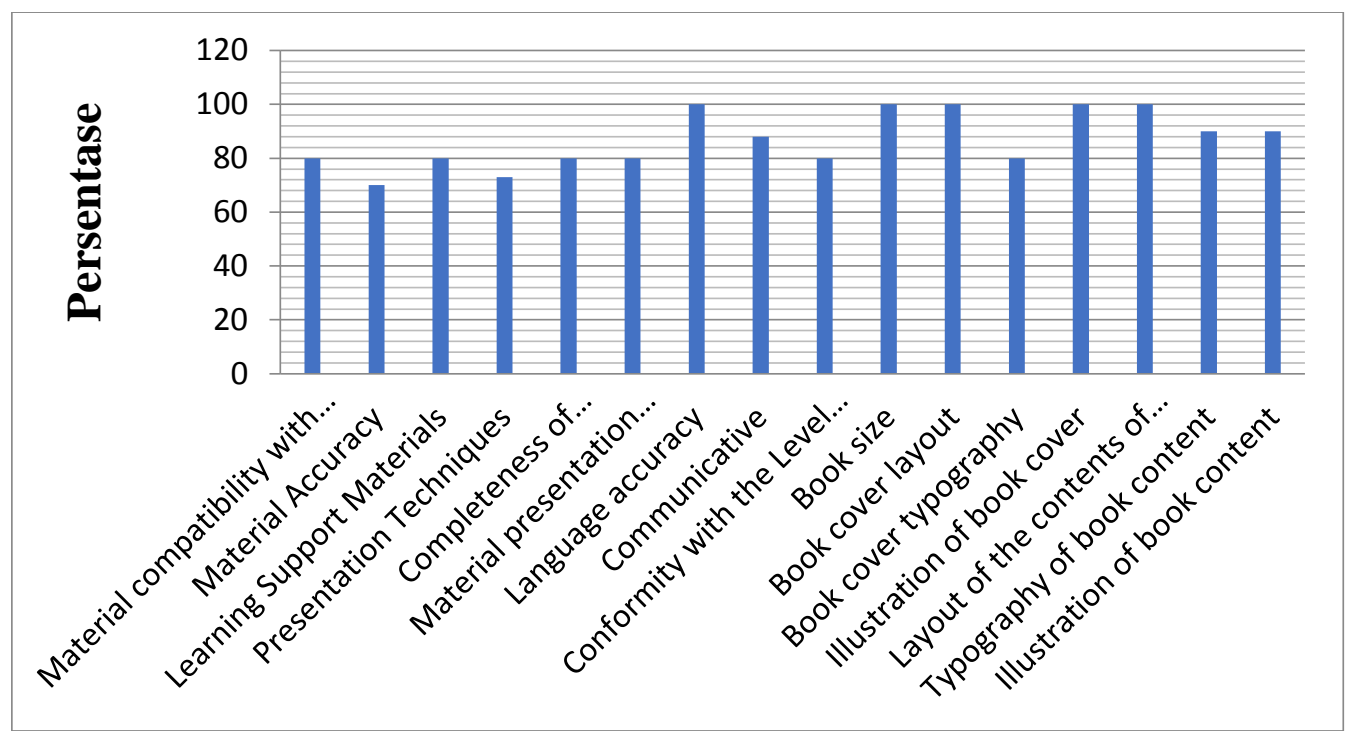

Fig. 3. The results of expert and practitioner responses.

The graph above shows that the response of material experts is high (77\%), language (92\%), media expert is very high $(95 \%)$ while the average results of expert judgment are very high $(86 \%)$. This result means that the compiled Student Worksheet does not need to be validated again and is already very applicable. Student responses to the worksheets developed can be seen in the following graph.

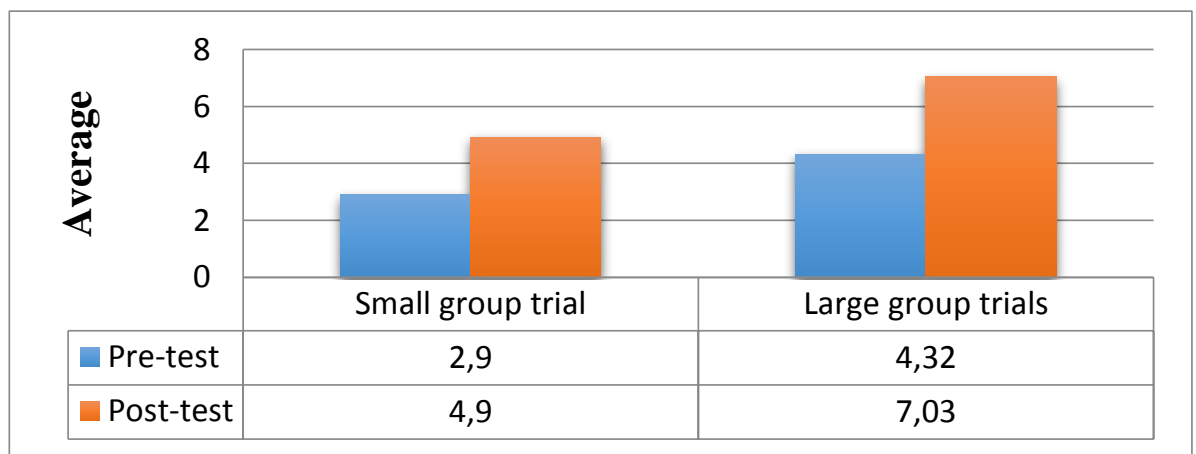

Fig. 4. The small and large group trials result.

The graph above shows students' responses to small group trials increased by $20 \%$, and large groups by $27 \%$. So, the worksheets that are compiled only need minor revisions and there is no need to try again, and the worksheets are very applicable to Composition's learning in the 
classroom. This result is reinforced by the high results of the questionnaire distributed to students after learning to use Student Worksheet as follows:

Table 2. The Student responses to the Student Worksheet.

\begin{tabular}{|cccc}
\hline No & Student Response & Percentage & Ket \\
\hline $\mathbf{1}$ & Small group trial & $85 \%$ & Very high \\
$\mathbf{2}$ & Large group trials & $86 \%$ & Very high \\
\hline
\end{tabular}

The schedule shows students' responses to small group trials are very high (85\%), as well as large groups ( $86 \%)$. So, the worksheets that are compiled only need minor revisions and there is no need to try again, and the worksheets are very applicable to Composition's learning in the classroom. This is coupled with the height of the teacher's response to the questionnaire.

Table 3. The Teacher's responses to the Student Worksheet.

\begin{tabular}{|cccc}
\hline No & Teacher's response & Percentage & Ket \\
\hline $\mathbf{1}$ & Small group trial & $96 \%$ & Very high \\
\hline $\mathbf{2}$ & Large group trials & $97 \%$ & Very high \\
\hline
\end{tabular}

Seen in the above schedule the teacher's response to the small group trial was very high $96 \%$, compared to the increase in the large group trial $97 \%$. So, the worksheets that are developed do not need to be revised and do not need to be retested, and the worksheets are very applicable to the composition's learning in class.

From small group and large group trial results data were analyzed descriptively using descriptive statistics aided by the Statistics Package for Social Science (SPSS version 22.0) software. as for the result:

Table 4. Paired Samples Test

\begin{tabular}{|c|c|c|c|c|c|c|c|c|c|}
\hline & & \multicolumn{5}{|c|}{ Paired Differences } & \multirow{3}{*}{$\mathrm{t}$} & \multirow{3}{*}{ df } & \multirow{3}{*}{$\begin{array}{c}\text { Sig. (2- } \\
\text { tailed) }\end{array}$} \\
\hline & & \multirow[t]{2}{*}{ Mean } & \multirow[t]{2}{*}{$\begin{array}{c}\text { Std. } \\
\text { Deviation }\end{array}$} & \multirow{2}{*}{$\begin{array}{l}\text { Std. } \\
\text { Error } \\
\text { Mean }\end{array}$} & \multicolumn{2}{|c|}{$\begin{array}{c}95 \% \text { Confidence } \\
\text { Interval of the } \\
\text { Difference }\end{array}$} & & & \\
\hline & & & & & Lower & Upper & & & \\
\hline $\begin{array}{c}\text { Pair } \\
1\end{array}$ & $\begin{array}{c}\text { Pre } \\
- \\
\text { Post } \\
\end{array}$ & $\begin{array}{c}- \\
2.3243 \\
2\end{array}$ & 1.82656 & 0.30029 & -2.93333 & -1.71532 & -7.740 & 36 & 0.000 \\
\hline
\end{tabular}

It can be seen in the table above that the $t$-value of 7.740 is greater than the t-table of 2.030 . So, this shows that there is a significant difference between the average scores of students pretest and post-test in large group trials. This also means that the worksheet products that are designed are effective in increasing the ability of student composition.

Based on the results of the study above, researchers can take several important points. Some research shows that the worksheets developed have decent and valid criteria with little revision and can be used as learning aids in class. Subsequent results found that the worksheets were included in very good criteria so that the design could continue to be produced with little improvement. These results are in line with the research results obtained by researchers that the response of material experts is "High" and linguists and media experts "Very High", the worksheets developed were only made minor revisions according to expert and practitioner input, then the worksheets could be tested on students. 
Students are very interested in giving positive comments to the worksheet, that with the worksheet in learning allows the teacher to interact with students. During the learning process, students can learn actively and efficiently by involving Student Worksheet. The expert's view is in line with the results obtained that the students 'response to the attractiveness of worksheets was considered very high so that the worksheets developed were very applicable in learning and enabled students' effectiveness in learning to run actively and efficiently.

Relating to the effectiveness of Student Worksheet graphic design with images and colors. Comenius's research found that the use of colors, schedules, graphics, and images gave good results in Latin language learning, in line with the preparation of worksheets enriched with the right picture concept in the learning environment that can attract students' attention [39, p. 119]. Strengthened by Karamustafaoglu, that conceptual drawings, questions, and cartoons can capture the attention of students. The expert's explanation is in line with the results of the study that students' responses to worksheets are considered to be very interesting in terms of writing, language, how to arrange pictures, and colors, complemented with evaluation, because evaluation in the form of questions is an important factor in worksheets [22]. Overall these results are in line with the results of research conducted by researchers.

The following example of a unit from a Student Worksheet that the author composed:

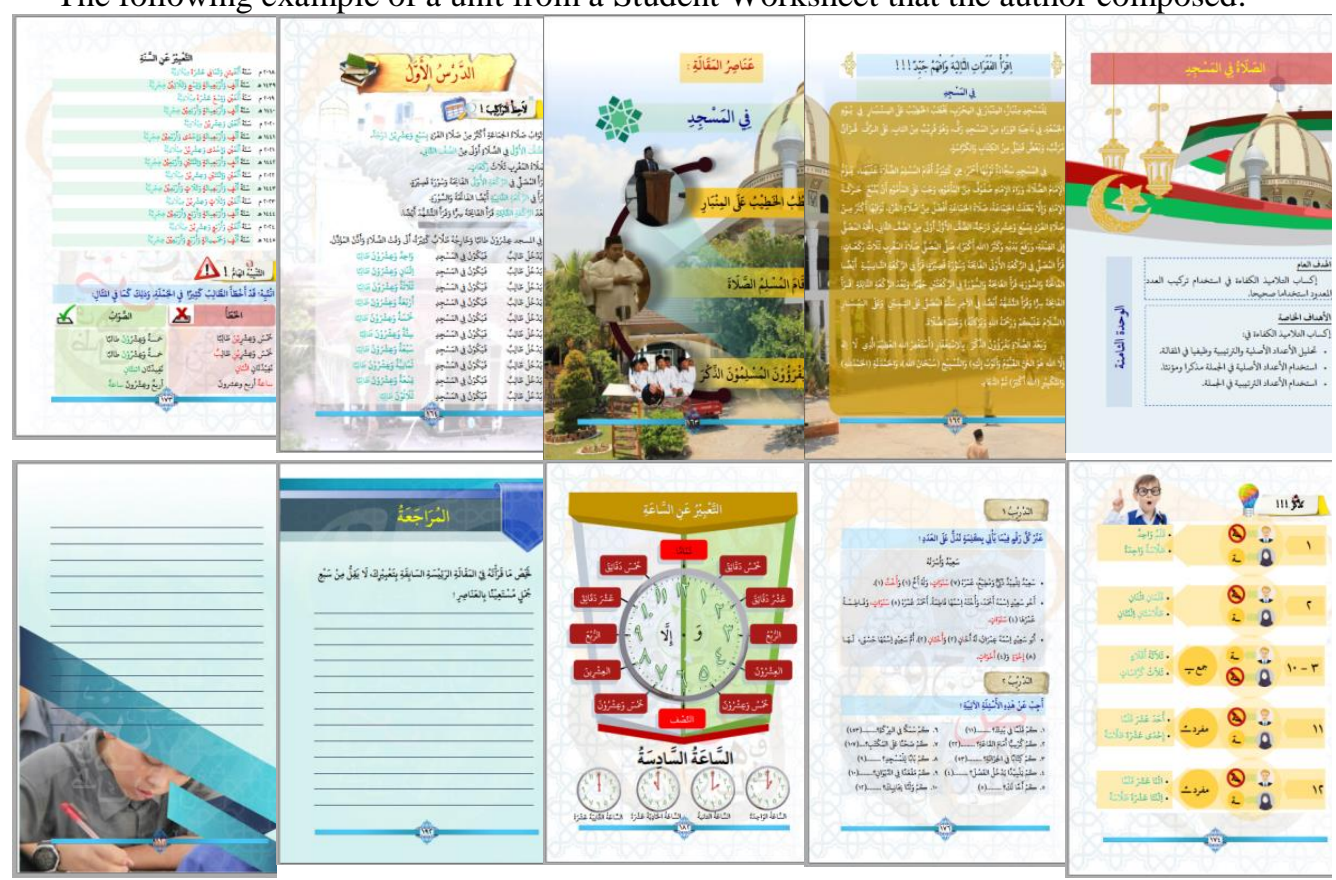

Fig. 5. example of a unit from a Student Worksheet

\section{Conclusion}

In addition to being a problem of students language problems, Composition's learning can also be a contribution to improving student's Composition abilities. Analysis of language errors as an applied linguistic theory can be used in which results are used as remedial material in the form of interesting teaching materials and following the abilities and development of students at that time. Student Worksheet is one of the teaching materials it's can be used by teachers in 
serving students in developing the ability of Composition in the learning environment. This research provides a positive contribution for teachers that the development of worksheets as important teaching materials in the learning process.

\section{Acknowledgements}

The authors would like to express their thanks to Kemenristekdikti for their support by Research Program for Magister Theses and the anonymous reviewers for their constructive comments and suggestions.

\section{References}

[1] A. Abdulhasyim, at-Ta'bir falsafatuhu, waqi'uhu, tadrisuhu. Oman: Dar al-Syuruq wa li an-Nasyr, 2010.

[2] K. 'Abdu Al-Fattah, Fannu at-Ta'bir al-Wadhifi. Maktabah manshur, 2002.

[3] E. Setiawati, Piranti Pemahaman Komunikasidalam Wacana Interaksional. Malang: UB Press, 2018.

[4] R. A. Thu'aimah, ta'lim al-Lughah Ittishaliyan baina al-Manahij wa al-Istiratijiyat. Dar al-Munadhamahh al-Islamiyah, 2006.

[5] R. Devianty, "Bahasa Sebagai Cermin Kebudayaan,” J. Tarb., 2017.

[6] M. S. Samak, Fannu at-Tadris li at-Tarbiyah al-Lughowiyyah wa intiba'atiha alMaslakiyah wa Anmatiha al-Ilmiyah. Cairo: Dar al-Fikri al-Arabi.

[7] P. P. Al-Iman, Silabus Kulliyatul Muallimin al-Islamiyyah. .

[8] J. C. Richards, Error analysis: Perspectives on second language acquisition. 2015.

[9] H. G. Tarigan, Pengajaran Analisis Kesalahan Berbahasa. Bandung: Angkasa, 2011.

[10] A. Prastowo, Panduan kreatif membuat Bahan Ajar Inovatif. Jogjakarta: Diva Press, 2015.

[11] A. F. Effendy, Metodologi Pengajaran Bahasa Arab. Jombang: Misykat, 2017.

[12] A. Al-Hadidi, Musykilatu ta'lim al-Lughah al-Arabiyah li Ghoiri al-Arab. Cairo: Dar al-Kitab al-Arabi.

[13] E. Rahmawati, "Pengembangan LKS dengan menggunakan pendekatan kontektual subtema lingkungan tempat tinggalku untuk meningkatkan hasil belajar pada siswa kelas IV Sekolah Dasar," J. Kaji. Pendidik. dan Has. Penelit., vol. 3, 2017.

[14] S. Pringgowidagda, Strategi Penguasaan Berbahasa, 1st ed. Yogyakarta: Adicita Karya Nusa, 2002.

[15] M. A. Q. Ahmad, Thuruq Ta'lim al-Lugah al-Arabiyyah. Kairo: Maktabah al-nahdhah al-Mishriyyah, 1979.

[16] S. 'Abdul K. 'abas Al-Waly, Tharaiq Tadris al-Adab wa al-Balaghah wa at-Ta'bir. Oman: Dar al-Syuruq wa li an-Nasyr, 2004.

[17] T. A. H. Al-Dulaimy, Al-Tharaiq al-'Amaliyyah fi Tadris al-Lugah al-Arabiyyah. Umman-Yordania: Dar al-Syuruq, 2003.

[18] Ali Ahmad Madkur, Funun Tadris al-Lugah al-Arabiyyah. Kairo: dar al-Fikr al-Araby, 1997.

[19] M. Khalilullah, "Strategi Pembelajaran Bahasa Arab Aktif (Kemahiran Istima' dan Takallum)," J. Sos. Budaya, vol. 8, 2011.

[20] A. W. Rosyidi, Memahami Konsep Dasar Pembelajaran Bahasa Arab, 2nd ed. Malang: UIN Maliki Press, 2012.

[21] A. Hamid, Mengukur Kemampuan Bahasa Arab Untuk Studi Islam, 2nd ed. Malang: UIN Malik Press, 2013. 
[22] T. Rahayu, Syafrimen, and W. Wati, "Lembar Kerja Siswa (LKS) Terpadu dalam Pembelajaran Fisika," in Proceeding of the 4th International Conference on Islam and Higher Education, 2016.

[23] Hasbullah, "Pengembangan Lembar Kerja Siswa Berorientasi Ketrampilan Proses dalam Pembelajaran Saintifik Terhadap Hasil Belajar Siswa pada Pokok Bahasan Sistem Pencernaan Manusia," J. Pendidik. Biol. Univ. Muhammadiyah Metro, vol. 7, 2016.

[24] R. L. Agustin, "Pengembangan Lembar Kerja Siswa (LKS) Berorientasi ChemoEntrepreneurship untuk Siswa SMA," Unesa J. Chem. Educ., vol. 3, 2014.

[25] U. Larasati, "Pengembangan Lembar Kerja Siswa (LKS) Fisika dengan Menggunakan Strategi Relating, Experiencing, Applying, Cooperating, Transfering (React) Berbasis Karakter pada Pokok Bahasan Hukum Newton,” J. Wahana Pendidik., vol. 2, 2017.

[26] M. I. Shini, At-Taqabul al-Lughawi wa Tahlilu al-Akhta'. ar-Riyad: Mathabi’ Jami'ah al-Malik Sa'ud, 1982.

[27] R. Ellis, Second Language Acquisition. Oxford: Oxford University Press, 2003.

[28] J. C. Richards, "Longman Dictionary of Language Teaching and Applied Linguistics," Longman Dictionary of Language Teaching and Applied Linguistics. 2013.

[29] Markhamah, Analisis kesalahan dan karakteristik bentuk pasif. Surakarta: Muhammadiyah University Press, 2014.

[30] S. N. Sridhar, "Contrastive Analysis, Error Analysis and Interlanguage: Three Phase of One Goal?, Study in Language Learning," ERIC, vol. 1, 1975.

[31] A. Jassem, J, Study on Second Language Learners of Arabic: An Error Analysis Approach. Kuala Lumpur: A.S. Noordeen, 2000.

[32] G. M. Johan, "Analisis Kesalahan Berbahasa Indonesia Secara Sintaksis dalam Proses Diskusi Siswa Kelas IV SDN MIRI,” J. Visipena, vol. 8, 2017.

[33] F. Sa'adah, "Analisis Kesalahan Berbahasa dan Peranannya dalam Pembelajaran Bahasa Asing,” J. Stud. Islam dan Sos. Univ. Islam Negri Walisongo, vol. 14, 2012.

[34] W. R. Borg and M. D. Gall, Educational Research: An Introduction. London: Longman, 1983.

[35] Sugiono, Metode Penelitian \& Pengembangan: Research and Development. Bandung: ALFABETA, 2015.

[36] P. B. Depdiknas, Kamus Bahasa Indonesia, 16th ed. Jakarta: Pusat Bahasa, 2008.

[37] T. Y. Al-Khathibi, al-Mu'jam al-Mufasshal fi al-I'rab. Libanon: Dar al-Kutub alIlmiyah, 2013.

[38] M. 'Ali Al-Khuli, al-Hayah ma'a Lughataini (at-Tsanaiyyah al-Lughawiyyah), 1st ed. Riyad: Jami'atu al-Malik Sa'ud, 1988.

[39] R. A. Thu'aimah, Manahij Tadris al-Lughah al-'Arabiyah bi at-Ta'lim al-Asasi. Qahirah: Dar al-Fikri al-'Arabi, 1998. 